\title{
『延喜式』新嘗会白黒二酒と 易・陰陽五行説
}

新當祭, 大嘗祭に神前に供える白酒・盗酒は，その製造方法か醍醐天皇の勅命により編集された律令の施行細 則法である「延喜式」に定められている。その中で黒酒を造る際に使用される木灰は久佐木（臭木）というクマ ツツラ科の低木の灰であるが何故久佐木を使うのか, また, 仕込配合や製成酒の数值は経験則によるものなのか, 筆者はそのことについて中国の「易」と「陰陽五行説」に基づいて仮説を展開する。

岩瀬平

\section{1. は じめに}

平成 2 年 3 月, 伊勢神宮神田を訪水, 神暬祭・両月妿次 祭の由貴大御䭚の御料とされるコメの栽培について聞く 機会があった。神田を辞し去るとき, 参考品種圃場に栽 培されていた丹波古代赤米, 中国黒米の種粐をいただい たが、これは生涯を山口県農業とともに歩んだ私にとっ ては心躍るいただきものであった。

平成 2 年と言えば, その秋践旅大嘗祭が行われた。こ の神事において, 年毎の新嘗祭とともに, 神酒に白酒・ 黑酒が供進されるといらことは故実に詳しい方のよく知 るところである。しかし, 神酒を醸すといらことは神事 であり他見を許さないのが通常であって, その実際を知 る人はほとんどいない。手にした古代赤米をみればその 玄米の色は濃い赤褐色, 黒米は漆黒である。日本に伝觉 られた最初のコメはジャポニカの赤米, それは糯であっ たろらというのが, 作物学, 民俗学, 文化人類学関係者 のおおよそ一致した見解とされていることから，古代の 酒はこらした有色米で造られていたであろら，そのと き, 有色米の種皮の色素が酒中に溶出し, 溶出した赤米 色素に詨して, 混和される久佐木灰が媒染剤的機作を持 って酒色を黒に近つけ黒酒が造られたのではなからう か, という想定が走った。加藤百一博士の『日本の酒 5000 年』11 によって尾張国正税帳に赤米 259 石を酒の料 として大炊寮に納めたといら奈良時代の記録のあること を知り，これに力を得て神宮赤米を用いて白酒・黒酒を 再現してみることとした。

幸いに山口県内精農家の協力を得て古代稲の栽培には いり, 山口県工業技術センターの格別の御配慮により, その研修制度にのせていただき，『延喜式』の「新嘗会 白黒二酒ノ料」に準拠して白酒・黒酒の再現試験を行う
ことができた。そして，それから得たものは，白酒に久 佐木灰を混和して黒酒を造るといら技法は, 久佐木灰 の媒染剤的機作を期待したものではなく，管分けられた 久佐木灰中にまじる消炭の微粉が直接的に白酒を黒酒に 仕上げるものであることを知ったのである。『延喜式』 の白酒・黒酒は清酒ではなく, 粥状のドブロクであっ て，そのことによって黒酒は全体が黒く仕上げられると いらことも分かった。当初の前提は全くと言っていいほ ぞ意味を持つものではなかったのである。

平成 4 年 11 月 23 日の新嘗祭を目標に造った白酒・ 黒酒のサンプルがある。半年，1 年を経過すると約 $40 \%$ 近い量の上澄み清酒が浮いている。その色調は, 白酒が 清澄な赤褐色, 黒酒のそれは一見黒に近い色調で透かせ ば深い濃赤褐色を呈し, 久佐木灰で収斂した灰黒色の醪 と区別できる。しかし，白酒・黒酒を造った直後のしば らくの間は上澄み清酒は浮いてこない。日数を経過して 浮いてくる清酒は醪とともにあるしばらくの間は, 白黒 いずれの場合も淡黄色（黒酒のそれは若干色調が強い） で推移する。その清酒を醪と分離すると, 前川・新家の 報告2) するように赤米の持つカテキン・タンニン系色素 が光に反応して一両日のらちに赤褐色に一変する。以上 のことから, 新嘗会の白黒二酒は清酒でなく粥状にすり つぶされたドブロクとして造られ, 神事終了まで不必要 な清酒は浮かないといら要件を備えたものとして造られ ていたと推察された。酒造りの安全性を確保するととも に, 汲水を総米の半量におさえた実際的根拠がここにあ ったのである。それは見事な経験則と呼ぶべきものであ った。

しかしながら, 白黒二酒再現試験の過程で新たに浮び 上ってきたのは, 最終的に一鹪より得られる酒量が 1 斗 7 升 8 合 5 勺と細かく規定されていることへの疑問であ

Hitoshi IWASE 
り，作業は 10 日のうちに愺るとされていることの意味 であった。これらは当時の造酒技術にかかるものとも推 察されるが，その数值をかく簃密に示すのにはそれなり の理由がなければならないであろら。さらにまた，白酒 から黒酒を仕上げるのに木灰，しかも久佐木の木灰が使 用されるのはなぜか, このことについても納得のいく解 釈が得られない限り,『延喜式』の白黑二酒を解明した ことにはならないのではないかと思われた。

それは，新嘗会の神酒として白酒・黒酒を構想した当 時の哲学思想一一易と陰陽五行説を拔きには，その解明 は不可能であろうことを示唆していた。

\section{2. 白酒・黒酒は神の酒}

百済の僧観勒が渡来し, 日本一暦・天文・地理・遁甲 方術の書をもたらしたのは西歴 602 年推古天皇 10 年で ある。国内的には各氏族の勢力伯仲して相い争うなか, これを鎮め統一国家への体制づくりが模索されていると きである。王権の安定と国家の秩序, 四時順行して民生 の安寧を確保することはまううごとの根幹であったか ら，宇宙原理を説きその認識の方法を述べた「易」の思 想は朝廷の中枢にいる知識層の深く学ぶところとなっ た。8世紀はじめに成立する『古事記』の序文, 創世記 の文章に『淮等南子』はじめ中国古典の言葉・文章表現が ひきうつしに近い形で述べられているという指摘はその 間の事情を物語っている。古事記・日本書紀編纂の指示 は天武天皇よりなされ，伊勢神宮の式年遷宮制が定めら れたのも天皇治世の時であり，日本における神事その祭 式が本格的整備されてくるのはこうした時代背景を持 つ7世紀から 8 世紀にかけてであったのである。そのと き，国家最大の祭祀である新嘗祭が当時の最高の哲学思 想であった易と陰陽五行説を援用してその祭式を構成す る面があったとしても沶かしくない。文学博士吉野裕子 氏が「伊勢神宮で重んぜられるのは，北辰の北と，天を 象る西北, 乾である。北玄天で黒, 西北怕である。 神酒の白酒・墨酒をはじめ, 神櫭では北を表わす水 と, 五味の中で北酒当される筬, つまり御塩とが, 白 色の米と並ぶ主要神饌である。海藻類も多分, 黒色を呈 する故に重じられているのであろう」゙) と, 易と陰陽五 行説から神致に解明の光をあてているのは極めて説得力 のある解釈である。加藤百一博士『日本の酒 5000 年』 が日前・俻䅫両神宮の酒造り神事を紹介するなかにも 同様のことが読みとれる。日前・国懸両神宮の酒造り神 事が「御酒水迎へ」から始まり,「御逶合せ祭」を経て, 「白御酒祭」で酒渵に水, 米粎, 蒸米を仕込み, 続いて 吉日を選んで「黒御酒祭」が行われ，黒御酒祭では白御 酒に莫亲灰，甘味をつけるために米赖，麦芽がさらに加
えられることが述べられている4)。白御酒から黒御酒が 醸されるにあたって, 吉日が選ばれ，臭木灰とともにさ らに米麴，麦芽が加えられるといらことは，黒御酒こそ 神酒中の神酒として酰されねばならなかったことを示唆 するものがある。その所以はどこにあったのであるう か。

中国明代の李時珍の著した『本草綱目』（1578）によ れば，中国北方を代表する作物「㯟」の項に，「弘景曰」 として陶弘景（456～536）の説を紹介している。その説 とは「黒㯟アリ程ト名ク, 酒醸シ祭祀ノ用二供フ」 （読下し筆者）である。陶弘景は神の言葉の書『眞誥』 の編著者, 茅山道教の天師であり中国宗教哲学史上淖 立する人物である。また天文・暦数に精しく，医術・中 国本草学の基礎を築いた碩学であり，梁の武帝は山中に 鿵棲する彼にしばしば治世を問い，世人は山中莘相と呼

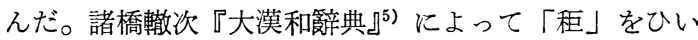
てみると「説文, 黒秋, 一稃二米, 以醸也」とみえ, 中

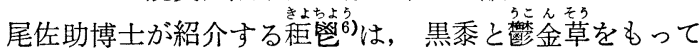
醇す酒で, 『大漢和辭典』は「香酒ナリ, 神习降ス所以 ナリ」と解説している。このことから古い中国にあって は，神祭に重きをなしたのが黒禁（程）て醸された酒で あったことが分かる。程粃は天地玄黄, 天の色 (䒾) と 地の色（黄）のまざりあら酒であった。

わが国の主殼はコメである。コメこそ高天原から伝来 された貴いものであった。黒米を手にしなかったとする ならば，造られた白酒から黒酒を造らなければならな い。このとき久佐木の木灰を混和して黒酒を仕上げると いう手法が選択された。新嘗会肆管”歌「天地と久乙 きまでに万代につかえまつらむ白酒黒酒を」（万葉集十 九）がよまれたのは孝謙天皇天平勝宝 4 年 (752) のこと であって, この頃には, 国家最重儀の祭祀たる新嘗会の 格式ある神酒として, 白酒・黒酒の位置は定っていたも のと考光られる。

\section{3. 新嘗会白黒二酒ノ料にみる易の数と理}

『延喜式』の新嘗会白黒二酒を造る技法を要約すれば 次のようになる。

米 1 石 (現行桝で 4 斗) のうち, 2 斗 8 升 6 合を势藥 （棃）につくり，残り 7 斗 1 升 4 合を蒸米とし，水 5 斗

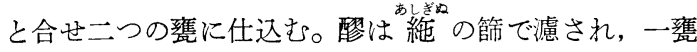
から 1 斗 7 升 8 合 5 勺の酒を得, 熟後一つの鹪に久佐木 灰 3 升を混和して黒酒となし，乙からざるものが白酒と された。造酒作業は 10 日のらちに畢わることとされ た。もとより作業に従事する者はト定して選ばれ，作業 開始は 10 月上旬（旧暦）吉日を選んで行われた。

この技法をみるとき，特徵となるのは総米 100 に対し 
て汲水が 50 と半量におさえられていることだが，その 理由はさきに触れた。上澄み清酒を必要としなかったか らである。つぎの特徴は, 椈歩合が 29 と高(7)ことで ある。これは加藤百一「神酒造りの伝承」の報告8) にみ るように, 神社の現行神酒造りの䴳歩合も $20 \sim 35 に$ 集中し, 『延喜式』造酒式にみる各酒類の䴯歩合も29～ 33 の間にあって, それは当時の酒造りの技術水準によ るところであったのであろらか。しかし，一甕より得る 酒の量を 1 斗 7 升 8 合 5 勺と戦しく規定することに出会 らと，それは単なる慣行数值によるとはいい得ない厳し さを感じさせる。さきにふれたように, 新嘗会の白酒・ 黒酒が中国の「易」と「陰陽五行説」に基づいて構想さ れた神酒であるとするならば,『延喜式』「白黒二酒ノ料」 に記述される数は軽々には扱えなくなるのである。「易 と五行説」から日本の祭祀を解明する吉野裕子は「易に 颃いては一切の森羅万象を数澴元し, それによって理 を究めてゆく 旾) もの捉兄ているのである。「易」では 数をどのように捉えているのか，これにふれて「新嘗会 白黒二酒, 料」に定められている数值の意味を問らこと としたい。

\section{1 易の数之天地・陰陽}

『易経熬锍上伝』には「天一地二。天三地四。天五地 六。天七地八。天九地十。」と記されていて，易では天 の数 (奇数) が一, 三, 五, 七, 九。地の数 (偶数) が 二, 四, 六, 八, 十。天の数は陽, 地の数は陰。「天の 数は五, 地の数は五, 五位相得て, 各々合う有り。天の 数は二十有五, 地の数は三十, 凡そ天地の数は, 五十有 五, 此れ変化を成して鬼神を行う所以なり」 ${ }^{10)}$ と述べて いる。ここで「五位相得て, 各々合う有り」とは, 大古 中国の聖王伏裁が天地の理を察して八卦, さらに六十四 卦を画したのは, 黄河から出現した龍馬の背に載ってい た眓 (河圖)を得てのことと言われ，その図に書かれて いた数の位置が北に (1と6), 南に ( 2 と7), 東に (3 と 8) 西に (4 と9), 中央に (5と 10) をいい, その各々の二つの数が陰陽相い和する形をとっているこ とを言っているのである。

\section{2 易の数と五行説}

漢代にはいって五行説が大いに行われ, 易の数に五行 が配された。北に水気（数では1と6), 南に火気 (2 と7), 東に木気 ( 3 と 8), 西金気 (4と9), 中央 に土気 (5 と 10)。五行とは万物を生ずる五元素（水火 木金土）とされ, この五気は, 水, 木を生じ, 木, 火を 生じ, 火, 土を生じ, 土, 金を生じ, 金, 水を生ずると 言われて，木火土金水の流れを生成順とした。さらに

$$
\begin{array}{cccccc}
1 & 2 & 3 & 4 & 5 & \text { は生数 } \\
6 & 7 & 8 & 9 & 10 & \text { は成数 }
\end{array}
$$

とし，1 は水を生ずる数，6は水を完成する数， 2 は 火を生じ 7 は火を完成する数……と考兄られた。吉野は この生数と成数の関係を『五行大義』論数を引用し, 「成数とならぬ水, 即ち生数 1 は凝滞して流れず, 生数 2 の火は炎光を発することがない........これらに各々 5 の 数を配して, 水は 6 の成数となってはじめてよく潤下 し, 火は 7 となってはじめてよく炎上する……」11)「要 するに生数は動か瀿, 成数は活躍する数であり, 恐ら く前者は体, 後者は用を本質とする数と私は推測する」12) といい, 吉野はさらに『尚書』「洪範」をひいて,「五行 は一に丽く水, 二に曰く火, 三に曰く木, 四に曰く金, 五に日く土。水に潤下といい, 火に炎上といい, 木に曲

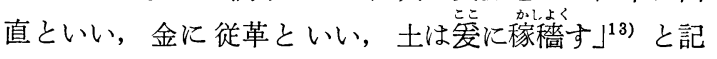
し, 土気の本質「土に稼穡す」とともに 5 の働きに注目 した。

\section{3 土気 5 の機能}

生数と成数の関係は次のようになる。

$$
\begin{aligned}
& \text { 成数 } 6=\text { 生数 } 1+5 \text { (水気) } \\
& \text { " } 7=" 2+5 \text { (火気) } \\
& \text { " } 8=" 13+5 \text { (木気) } \\
& \text { " } 9=" 4+5 \text { (金気) } \\
& \text { " } 10=" 15+5 \text { (土気) }
\end{aligned}
$$

生数1 $\begin{array}{llllll}2 & 3 & 4 & 5 \text { を活動する成数たらしめるのが } 5\end{array}$ の働きであり， 5 は，河圖にしるされた 1 と 6,2 と7, 3 と 8,4 と 9,5 と 10 の「二つの数をつなぐ重大な 役割を持つが，乙かし表面からは全く見立ない。二つの 数をつなぎはするが，その結合が成就した時点では既に 消去して跡方もない」14) とした吉野の創見は傾聴に值す る。土気は万物を育むと同時に万物を消去・死滅させる のであり, 土気の持つこの両儀性は土気の顕著な特質を なしているという。

かくして, 天の数（奇数）を合わせると 25, 地の数 (偶数)を合わせると 30 ，したがって，その和 55 は天 地の数。「河圖にあらわれて居る一から十までの数, 合 計して五十五の数によって, 天地間の有らゆる変化が完 成し, 陰陽の消長盛衰, 即ち天地霊妙不可議なる鬼神の 大いなる働きも，これによって窥ひ知られる」51 とした のが「易」の数を捉える立場である。

\section{4 新嘗会白黒二酒亡易・五行説}

以上の易の数の理と陰陽五行説をらまえて,「新嘗会 白黒二酒, 料」に述べられた造酒技法の解析に進むこと としたい。その解析にあたって念頭におかなければなら ないのは, 新嘗会といら祭祀は今年の収穫を感謝し来る 年の豊穣を祈る祭であるといらことである。陰陽五行説 で土気の本質は「土に稼穑す」であった。「稼」とは土 に種を播くことであり，「穡」とは土から収穫すること 


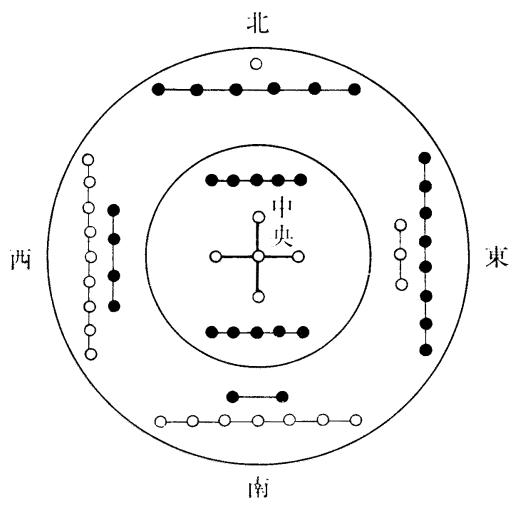

河汹
である。この土気の本質は新嘗会の祭祀目的と一致す る。五穀の豊かな生育と収穫は四時順行することによっ て期待することができるのであり，この四季の順当な推 移もまた土気の支配するところである。四季の終わり 18日間は土気の支配する「土用」である。この土用を経 ることによって, 例えば, 春が消滅し夏が生成してくる と考光られたのである。かく深く農事にかかわる土気の 働きを高めることこそ，五穀豊穣を祈る祭祀一新嘗会の 目的に沿らものであった。このよらに新嘗会を土気の祭 と捉えるなら，この神祭に供えられる神酒むまた土気を 踏えてこそこの祭祀の神酒たり得ると言えよう。次にみ るように,「新嘗会白黒二酒ノ料」にみる造酒技法は見 事なまでにその間の消息を達成していたのである。

(1)総米 1 石之汲水 5 斗佂て

総米 1 石は 10 斗, 10 は土気成数（盈数を払えば 1, 水気汇還元される)。 汲水 5 斗の 5 は土気生数。

原材料とされるコメと水, それは土気成数 10 と 土気生数 5 をろえ, 土気完成のかたちをとって用 意される。

(2)䊍米にあてられるコメは 2 斗 8 升 6 合。その数を合

せれば, $2+8+6=16$

$$
16=10+6
$$

活動する土気成数 10 之活動する水気成数 6 の組 み合わせとなる。酒造りの主役である麳のめざまし い作用を象徴するものとなっている。

(3)掛米となるコメは残り 7 斗 1 升 4 合であり，これは

飯に炊かれる。7+1+4=12

$$
12=10+2
$$

となって, 土気成数 10 と, 火気生数 2 とで構成 される。ここに火気の生数 2 があるのは, 飯に炊か れる掛米として理にかなう。

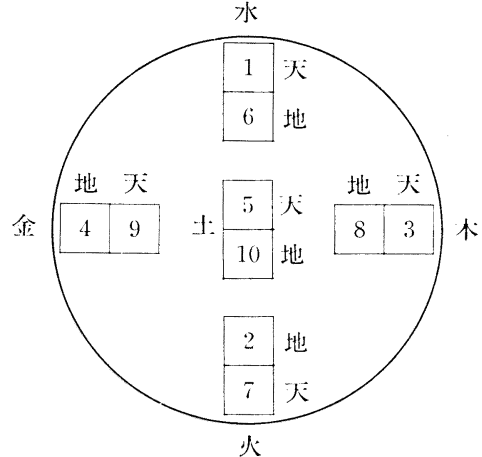

吉野裕子『神々の誕生』より

(4)一雔から 1 斗 7 升 8 合 5 勺の酒を得る。

白酒と黒酒二萑だから酒量はその倍, 3 斗 5 升 7 合となる。七・五・三といら目出度い数の配列であ るが, $3+5+7=15$

$15=10+5$

となって, 最初に用意される原料の総米 10 と汲 水の 5 と同じように, 最終成果である酒量もまた腽 んなる土気成数 10 と生数 5 を得て土気は完成され る。

(5)久佐木灰 3 升を混和して神の酒たる黒酒を造る。

3 は木気生数である。久佐木の木灰であるから当 然のこととして理にかなら。しかしそれはまた天・

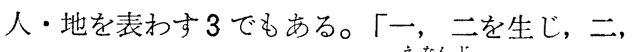
三を生じ，三，万物を生ず」(『淮南子』）と言われ $て^{16)}$, 天地の間の万物万象を生み出す三才を表わす とすれば，宇宙万象を主宰するの神酒（黒酒）の誕 生をみるにふさわしいことになる。かくして新嘗会 白黒二酒製造の作業はしめくくられることになる。 (6)酒を造る作業は 10 日のらちに畢るということ。

この定めも，新嘗会の祭祀が土気を本質とする祭 祀なるが故に, 土気成数 10 を超えてはならないと 観念されたのであろう。

(1)から6)を通して考察すると，飯となる掛米に火気生 数の 2 を, 混和される久佐木灰に木気の生数 3 をるるほ かは, 酒の本質たる水気の成数 6 または生数 1 , 祭の主 旨にかなら土気の成数 10 と生数 5 をべースに一貫して 構成されていることが分かる。私にとってこれは驚くべ きことであった。

当時継承された造酒技術の最先端に立ちつつ, その時 代を創る最高の哲学思想であり, 宇宙万象の認識手法で あった易と陰陽五行説を精繳なまでに駆使して規定した のが,「新嘗会白黒二酒ノ料」の内容であることを知った 
とき，一点一画を抢ろそかにすることなく神の酒を醸し た古人の, 周到なまでの配意とその熱誠に呑まれる思い であった。これが一見ただの乱数のごとくにみえる「新 嘗会白黒二酒ノ料」にしるされた諸数值に蔵されていた 易の数の理, 構図であったのである。

\section{4. 久佐木灰使用にみる陰陽五行説}

『延喜式』新嘗会白黒二酒の原料に赤米が用いられた か, それは白米であったか，それについては明記されて いない。当時の造酒技法は醖方式であったから粘性の低 い赤米が用いられた可能性がないわけではない。明代の 『本草綱目』にも粳あるい㴞について，「赤者酒多クシ テ糟少シ」と言っている。しかし，白酒から黒酒を造る 技法が久佐木の木灰にまじる消炭の微粉によって直接的 に灰黑色に仕上げるものであることを知ると，原料米に 赤白を問ら必要はなく, 用いる木灰がなぜ久佐木の木灰 でなければならないか, 解くべき課題はその一点にしぼ られてくる。

医を家業ともした本居宣長は混和される木灰を薬灰と とらえているが17), 久佐木が漢方生薬として格別淖効 があるよらにも見受けられず，葉をちぎればいやな旬い

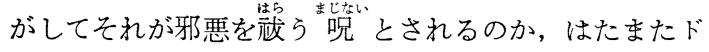
ブロクの酸味を中和するためなら燃え切った白い木灰こ そ望ましいのではないかなど，まことに不安定な解釈を どうどう巡りしているとき, 美保神社 (島根県八束郡美 保関町, 旧国幣中社) の著名な諸手船神事に打参りし た。祭日は 12 月 3 日。美保神社新嘗祭が行われる。前 夜の宵祭は献饌が中心であり, 巫女の捧げる延導幣を先

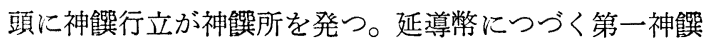
は，金䈃の神紋を配した黒㴍の台盤に，これまた黒漆の 枠に真っ白の和紙の張られた行燈型の覆いがかけられて いる。注連のかかったその覆いの中にあるのは大椀に盛 られた和うわといら。奉持されて進むその第一神饌の覆 いの上には奉書でつくられた箸袋が載せてある。翌日寸 べての神事が終って伺ったところによると, その箸袋に 納められている筹はクサギでつくられている，というこ とであった。それを耳にしたとき私は一瞬茫然となっ た。これを聞いて以来, 古人はクサギにある特別な意味 をみていたと確信せざるを得なかった。それから本番の 『延喜式』白黒二酒の再現試験にとりかかるのだが，久 佐木とは何かを自問自答しつつ日を過すこととなった。

再び『延喜式』を読み返し原点に立ってみると, これ を解く「鍵」は『延喜式』のなかにあった。

その一つは, 『延喜式』「白黒二酒ノ料」の記述のなか の「久佐木灰三升」の下に書かれている割註の六文字で あり,その二は, 『延喜式』巻三十七の「典薬式」はク
サギを本来の文字「恒山」で記述しているといらことに あったのである。

その一。「白黒二酒ノ料」の久佐木灰三升の下の割註 とは,「採二御生気方木一」の六文字である。「御」とは 『延喜式』を通して読むとき，それは天皇を意味する文 字であることが分かる。「尘気の妿」とは，九星の占い によって吉とされる方角ということである。したがって 割註の六文字は, 「天皇御生年の星と今年の星との関係 からみて吉とされる方角の木を採れ」と指示しているの である。『延喜式』の白酒・黒酒にふれて「ある種の草 木の灰」などと言った語呂合わせの解釈はも早や通用す るものでないことが分かる。これほどまでに重きをなす 久佐木であった。では久佐木とは何か, これを次にみた いと思う。

その三。『延喜式』巻三十七の「典薬式」は, 伊勢の 国から恒山 10 斥, 丹波の国から恒山 8 斥を朝廷に納め ることを規定している。造酒式では久佐木だが, 典薬式 はクサギを本来の文字「恒筧」で表記しているのであ る。諸橋轍次『大漢和節典』18) によって恒山をみれば, 中国の名山とされる五獄のうち北誩が恒山である。恒山 が漢の文帝の誈であることからこれを敔って中国ではク サギを常山と表記するようになるが，典薬式は本来の 「恒山」で表記しているのである。五獄とは東の泰山, 西の華華, 北の恒山, 南の衡山, 中央の高山蓄山ことであ る。古代中国の天子はこの五獄を巡行し, 山の神霊を祀 って国の安泰を祈ったと言われる。北は神の尘すとこ 万, 配される色は黒, 配当される五気は水気である。水 気の曈んなるもの酒であるとするなら，国家の最重儀で あり天皇親祭の祭祀たる新嘗会 (祭) 飞奉献される神酒 中の神酒たる黑酒は, 天皇生気の妿に生える惊山茾の木灰 によって仕上げられてこそ，首尾を一貫することができ るといらものであった。これが新賞会の神酒白酒から黒 酒を仕上げるのに久佐木灰が用いられる理由であった。

新嘗会は古来霜月（陰暦 11 月，子垫の月）の即の日の 夜行われた。陰月 11 月子の月は陰極って一陽萠す卦の 月であり, 那の日（二度のときはあとの卯の日, 三度あ るときは中の卯の日）は冬至の節気のなかにある。陰か ら陽へ転換し新しい生命が生れるターニング・ポイント の大切な時点である。穀粒も一粒のなかに全生命活動を 凝集し, 春に備えている時節である。水気最も旺んな子 の月が選ばれたのは五気相生順によって水気は木気を生 むからであり，木気（作物は木気）最も旺んな卯月（旧 2 月）を予祝してのことである。収穫を感謝し来る年の 豊作を祈り，そのための四季順当なる推移を願う新嘗会 は土気の祭であったが，土気に配される季節はない。土 気は現実の事象を超えて機能するものだからである。し 


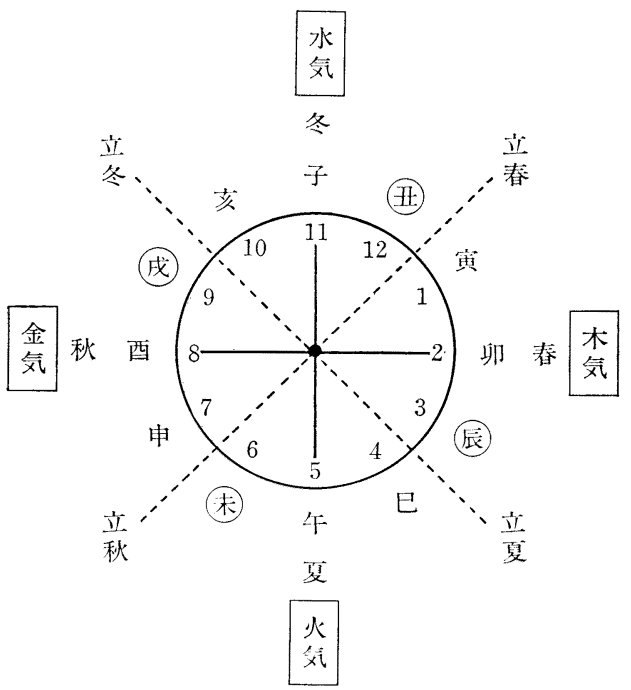

アラビア数䆘は旧暦の月を示す。

一年の構造図（吉野裕子『易と日本の祭祀』より）

註，开展来戍屿用をもつ月。

たがって, 新嘗会 (祭) の斎行される祭祀の日は, 木気 を育てる水気最も旺んな子の月, 卯の日の夜が選ばれる こととなったのである。

\section{5. ま と め}

新嘗会の白酒・黒酒は, 当時の造酒技術の最先端に立 ち，かつ，天地・自然・人間の事象を認識する手法であ った中国の易と五行説を援用して精緻なまでの配意のむ とに奈良時代に構想された神酒であった。

新嘗会白黒二酒は, 総米 1 石を用意し，これを麴に 2 斗 8 升 6 合を, 残り 7 斗 1 升 4 合を蒸米にして水 5 斗々 合わせ, 二つの鶽に仕込んで一甕から 1 斗 7 升 8 合 5 勺 の酒を得, 一隼に久佐木灰 3 升を混和して黒酒となし, しからざるものが白酒とされた。したがって, 得られる 総酒量は 3 斗 5 升 7 合であった。これらに配当されてい るそれぞれの数をたしてみると, 総米 1 石の 10 斗と汲 水 5 斗は $(10+5)$, 宷は $16(10+6)$ となり, 掛米は $12(10+2)$, 総酒量は $15(10+5)$ となって, 飯に炊か 孔る掛米 (蒸米) に2 烒があり, 久佐木灰量に 3 の 木気をみるほかは，すべて土気の成数 10 と土気生数 5 を基本として構成されていた。主役となる䊝には, 活動 する数とされる土気の成数 10 と水気の成数 6 が配当さ れていた。水気の成数 6 を棦にみるのは, 酒が水気最も 旺んなるものであるから, 酒を生み出寸䊝には土気成数 10 と水気成数 6 が配されたのであろら。生数は実体を

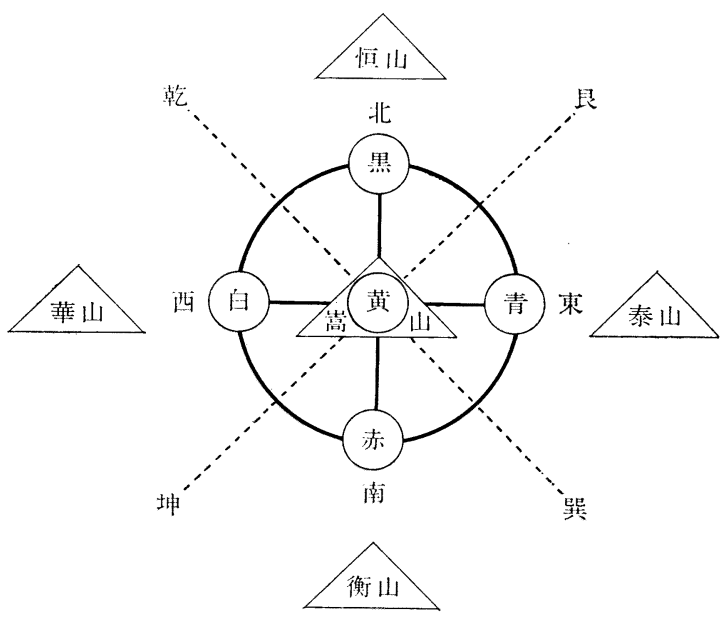

五方・五色・五魰配当四

註）青は緑のことである。

生む数, 成数は活動する数とされているのである。新嘗 会が土気（ここに稼穡す）を本質とする祭であることか ら，それに供えられる神酒もまた土気を踏えて醸されて いたのである。使用する木灰に久佐木が選ばれたのは, 古代中国で国の鎮めの名山とされた北該恒山がクサギ本 来の文字であることに由来した。神酒中の神酒たる黑酒 を仕上げるにはさらに慎重な配慮がなされた。それはそ の年の星と天皇御生年の星とからト定される吉方に生宇 る久佐木から使用する木灰はつくられた。新嘗会は国家 最重儀の祭祀であり天皇親祭の祭であったからである。

これが新嘗会白黒二酒を造る技法のなかに蔵されてい た易の数の理と五行説に基づく意味の構図であった。 祭祀の本質が陰陽五行説にいら土気の祭なるが故に, 新 嘗会の白酒・黒酒の造酒技法に駆使された易と五行の理 は, 今日まで永くヴェールに包まれるものとなった。土 気は具体的な現実の事象を超えて機能するものであった からである。

新嘗祭は日本民族の精神文化の中核に位置する祭祀と して今日に伝承され, 宮中祭祀のなかの最重儀として連 綿と承け継がれてきた。これに供進される神酒はいます 白酒, 黒酒である。伊勢神宮三節祭り献供される邑貴 大架御餄の神酒にも白酒・黒酒の名がみえる。それは, 過去 に構想された文化事象の単なる継承であろらか。最後に 21 世紀の思想状況をひらく旗手の一人として著名な動 物行動学のライアル・ワトソンの『スーパーネイチャー 
II』にひかれた, カリフォルニア大学のブリント・バー リンとポール・ケイの, 世界の 98 種類の言語を調査し て得た発見を紹介してまとめのしめくくりとしたい。

それは要約すると，「色彩を描写する用語に自然なス ペクトルが存在する。三つの色彩語を使う場合はすべて 黒と白の次に赤が加わり, 四つの場合は黒・白・赤につ いで緑が, 五番目にはたいてい黄が, 六番目に青, 七番 目に茶が続き, いつもこの順で登場する」 ${ }^{19)}$ というので ある。民族の文化の個性を超兄て出てくる「この驚くべ き規則性については，適切な説明がまだないが，少なく とも何らかの共通体験をしているということは心強い話 である。とライアル・ワトソンは言っている。この色 彩語に現われる規則性は, 古代中国の人々が捉えた自然 認識（五色の配当）と一致する。このことから言えるこ とは, 初発の色である白と黒は, 神より出, 神とともに ある色と言って過言ではあるまい。かく捉えるとき，白 酒, 黒酒は時を超えるものを持つことになると言えよ 5 。

古代稲を手にすることから始まった『延喜式』白黒二 酒の再現試験は, 神酒としてのその実際を確認すること のほかに，思いもそめなかった分野に分け入ることとな り, 造酒技法の背後に蔵された意味の構図を探求する作 業となった。浅学にしてよくそのことをなし得たかどう か，大方の御批判を乞うところである。

『延喜式』の白黒二酒の再現試験実施にあたっては各 方面の方々の御支援と御厚意に支えられてことをすすめ ることができた。古稀をこえた一老農学徒が造酒試験と いら得難い機会を持ち得たのは, ひとえに山口県工業技 術センタ一諸木保彦所長の格別の御高配と御支援による ところであり, 同センター食品工業部の研究員の皆さん の御親切な助言, わけても酒造りにはズブの素人である 私の手をとって終始懇切な指導と助言を惜しまれなかっ た柏木享醱酵食品科長の御指導のたまものであった。ま
た中国黒米・神宮赤米の栽培にあたられた長門市宮本孟 氏はじめ山口県内精農家の方々の御協力があってのこと でした。ここに関係各位の皆さんに深く謝意を表しま す。また創見にみちた著書を通じて得た吉野裕子博士の 学恩なくしては本稿の前半は成らなかったであろら。あ わせ謝意を述べてお礼としたい。

（元山口県農業試験場長）

文献

1）加藤百一：『日本の酒 5000 年』p. 88 技報堂出版， (1987)

2）前川季義・新家龍 : 醸協, 84, (11) 787 (1989)

3）吉野裕子：『大嘗祭』p.75 弘文堂（1987）

4）加藤百一：『日本の酒 5000 年』, p.79 技報堂出 版 (1987)

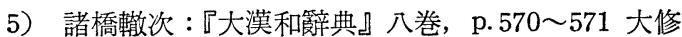
館書店 (1967)

6) 中尾佐助:『食の科学』「東アシシアの酒文化」No. 47, p. 28 丸ノ内出版 (1979)

7）加藤百一：『日本の酒 5000 年』, p. 100 技報堂出 版 (1987)

8）加藤百一：醸協, 73，（11） 862 (1978)

9）吉野裕子：『大嘗祭』p.169, 弘文堂 (1987)

10）公田連太郎述：『易経講話五』（復刻版）「熬爵上 傳) p.179，明徳出版社（1989）

11）吉野裕子：『神々の誕生』, p. 269 岩波書店 (1990)

12）吉野裕子：『神々の誕生』，p. 269 岩波書店 (1990)

13）吉野裕子：『神々の誕生』，p. 265 岩波書店（1990）

14）吉野裕子：『大嘗祭』p. 171, 弘文堂 (1987)

15）公田連太郎述：易『経講話五』（復刻版）「繫節上 傳」, p.181 明徳出版社 (1989)

16）吉野裕子：『易と日本の祭祀』，p. 27 人文書院 (1948)

17）石橋四郎編 :『和漢酒文献類聚』「酒襍志」復刻版, p. 18 第一書房 (1976)

18）諸橋轍次：『大漢和嘸典』四巻, p. 1022 大修館 書店（1967）

19）ライアル・ワトソン：『スーパーネイチャーII』 p. 326 日本教文館（1988）

\section{執筆者紹介（順不同・敬称略）}

岩 瀬 平 $<$ Hitoshi IWASE $>$

大正 11 年 9 月 30 日生れ<略歴 $>$ 昭和 23 年東京大学農学 部農学科卒, 同年山口県に奉職, 44 年山口県農林部普及 教育課長，47年山口県営農技術研修所長，54年山口県農 業試験場長, 56年山口県を退職, 山口県立農業大学校, 宇部短期大学非常勤講師を経て, 目下自適。その間に山 口県農業の指導に当るく抱負〉古社などに伝承されてい る神饙の調查研究く趣味〉木洩れ日の下でゴロリと寝て 空を仰ぐこと。
田村 學造 $<<$ Gakuzo TAMURA $>$

大正 13 年 8 月 20 日生和 $<$ 略歴 $>$ 昭和 22 年東京大学農学 部農芸化学科卒, 24 年同大学農学部助手, 34 年同大学農 学部助教授, 44 年同大学農学部教授, 60 年停退官 (同大 学名誉教授), 60年東京理科大学工学部教授, 63 年同大学 退職, 63年(株)醸造資源研究所長, 63年東京農業大学農 学部客員教授 $<$ 抱負 $>$ 微生物機能の探究 $<$ 趣味 $>$ 絵画, 陶磁器鑑賞。 